\title{
XVIII. An analysis of several varieties of British and foreign salt, (muriate of soda,) with a view to explain their fitness for different œconomical purposes
}

\author{
William Henry M.D. F.R.S.
}

To cite this article: William Henry M.D. F.R.S. (1810) XVIII. An analysis of several varieties of British and foreign salt, (muriate of soda, ) with a view to explain their fitness for different œconomical purposes, Philosophical Magazine Series 1, 36:148, 106-119, DOI: 10.1080/14786441008563149

To link to this article: http://dx.doi.org/10.1080/14786441008563149

$$
\text { 曲 Published online: } 18 \text { May } 2009 .
$$

Submit your article to this journal ¿

\section{山ll Article views: 2}

Q View related articles ¿ 


\section{$\left[\begin{array}{ll}106 & ]\end{array}\right.$}

XVIII. An Analysis of several Vurieties of British and Foreign Salt, (Muriate of Soda,) with a view to explain their Fitness for different aconomical Purposes. By William Henry, M.D. F.R.S: Vice-Pres. of the Literary and Philosophical Society, and Physician to the Infirmary at Manchester*.

\section{SECr. I. General Observations.}

$I_{N}$ undertaking the series of experiments described in the following pages, I had not su much in view the discovery of novelties in science, as the determination, by the careful cmployment of known processes, and by the improvement of methods of analysis, of a number of facts, the establishment of which (it appeared to me probable) might have an influence on an important branch of national revenue and industry.

An opinion has for some time past existed, and I believe has been pretty general both in this and other countries, to the disadvantage of British salt as a preserver of animal food; and a decided preference has been given to the salt procured from France, Spain, Portugal, and other warm climates, where it is prepared by the spontaneous evaporation of sea water. In conformity with this opinion, large sums of money are annually paid to foreign nations, for the supply of an article, which Great Britain possesses, beyond almost any other country in Europe, the means of drawing from her own internal resources. It becomes, therefore, of much consequence to ascertain, whether this preference of foreign salt be founded on accurate experience, or be merely a matter of prejudice; and, in the

\begin{tabular}{llll} 
White lyas, with shining spangles, of Wells & & & Grains. \\
Brown limestone, of Plymouth &. & $\ldots$ & $1 \frac{1}{4}$ \\
\hline
\end{tabular}

Forty grains of burnt lime in flower, dissolved in aquafortis, left of clayey matter when dried in the sun, as follows, viz.

\begin{tabular}{llllll} 
Blue lyas, of Watchet & $\ldots$ & $\ldots$ & $\ldots$ & $\ldots$ & 4 表 \\
\hline
\end{tabular}

The Watchet (residuum) made into a ball just stuck together, the Briddistow scarcely."

When I was at the house of Mr.Jessop the engineer (who was formerly a pupil and assistant of $\mathrm{Mr}$. Sineaton) at Butterley in Derbyshire, he mentioned that a Mr Tofield, a civil engineer of the southern part of Yorkshire, formed a design 50 years ago, of investigaing the British strata. I shall be thankful to any of your readers who can communicate any particulars of this undertaking, and of its author, if they will do so.

- Erom Philosophical Transactions for 18 10, Part I. 
former case, whether any chemical difference can be discovered, that may explain the superiority of the one to the other.

The comparative fitness of these varieties of salt for the curing of provisions, which has been a subject of much controversy among the parties who are interested, can be decided, it is obvious, in no other way, than by a careful examination of the evidence on both sides. Where evidence, however, is doubtful, and where there exists, as in this case, much contrariety of testimony, it cannot be unfair to yield our belief to that which best accords with the chemical and physical qualities of the substances in question. Again, if salt of British production should be proved to be really inferior in chemical purity to foreign salt, it would be important to ascertain, as the basis of all attempts: towards its improvement, in what, precisely, this inferiority consists. It seemed desirable, also, to examine whether any differences of chemical composition exist among the several varieties of home-made salt, which can explain their variable fitness for oconomical purposes.

Such were the considerations that induced me to undertake an inquiry, which has occupied, for several months past, a large share of my leisure and attention. I began the investigation, wholly uninfuenced by any preconceived opinions on the subject; and $\mathbf{l}$ had no motive to see the facts in any other than their true light, since I have no personal interest, either directly or remotely, in the decision of the question.

The principal sources of the salt, which is manufactured in this country, are rock salt, brine springs, and sea water. The first material is confined entirely, and the second chiefly, though not wholly, to a particular district of Cheshire. Of the extent and boundaries of this district, the process of manufacture, and other circumstances interesting to the mineralogist as well as to the chemist, an ample and excellent history has been given by Mr. Henry Holland, in the agricultural report of the county of Chester*. From his account, I shall extract, in order to render some parts of this memoir more intelligible, a very brief statement of the characteristic differences of the scveral varieties of salt, which are prepared in Northwich and its neighbourhood.

In making the stoved or lump salt, the brine is brought to a boiling heat, which, in brine fully saturated, is $220^{3}$

* Published in 1808. 
of Fahrenheit. This temperature is continued during the whole process; and as the evaporation proceeds, small flaky crystals continue to form themselves, and to fall io the bottom of the boiler. At the end of from eight to twelve hours, the greatest part of the water of solution is found to be evaporated ; so much only being left, as barely to cover the salt ard the bottom of the pan. The salt is then removed into conical wicker baskets, termed larrows ; and, after being well drained, is dried in stoves, where it sustains a loss of about one-seventh of its weight.

On the first application of heat to the brine, a quantity of carbonate of lime, and sometimes a little oxide of iron, both of which had been held in solution by an excess of carbonic acid, are separated; and are either removed by skimming, or are allowed to subside to the bottom of the pan, along with the salt first formed, and with some sulphate of lime; and are afterwards raked out. These two operations are called clearing the pan. Some brines scarcely require them at all, and others only occasionally. The whole of the impurities, however, are not thus removed; for a part, subsiding to the bottom, forms a solid incrustation, termed by the workmen pan-scale. The portion of this, which is lowest, acquires so much induration and adhesion to the pan, that it is necessary to remove it, once every three or four weeks, by heavy blows with a pick-axe. These sediments are formed, also, in making the other varieties of salt.

In preparing common salt, the brine is first raised to a boiling heat, with the double view of bringing it as quickly as possible to the point of saturation, and of clearing it from its earthy contents. The fires are then slackened, and the evaporation is carried on for 24 hours, with the brine heated to $160^{\circ}$ or $170^{\circ}$ Fahrenheit. The salt, thus formed, is in quadrangular pyramids or hoppers, which are close and hard in their texture. The remainder of the process is similar to that of making stoved salt, except that after being drained it is carried immediately to the storehouse, and not afterwards exposed to heat, an operation confined to the stoved salt.

The large-grained flaky salt is made with an evaporation conducted at the heat of 130 or 140 degrees. The salt thus formed is somewhat harder than common salt, and approaches more nearly to the cubic shape of the crystals of muriate of soda.

Large-grained or fishery salt is prepared from brine heated only to $100^{\circ}$ or $110^{\circ}$ Fahrenheit. No perceptible agitation, 
agitation, therefore, is produced in the brine, and the slowness of the process, which lasts from seven or eight to ten days, allows the muriate of soda to form in large, and nearly cubical crystals, seldom however quite perfect in their shape *

For ordinary domestic uses, stoved salt is perfectly sufficient. Common salt is adapted to the striking and salting of provisions, which are not intended for sea voyages or warm climates. For the latter purposes, the largegrained or fishery salt is peculiarly fitted.

On the eastern and western coasts of Scotland, and especially on the shores of the Firth of Forth, large quantities of salt are made by the evaporation of sea water. In consequence of the cheapness of fucl, the process is carried on, frum first to last, by artificial heat, at a temperature, I believe, equal or nearly so to the hoiling point, and varying, therefore, according to the concentration of the brine. The kind of salt, chietly formed in Scotland, approaches most nearly to the character of stoved salt. In some places a salt is prepared, termed Sunday salt; so called, in consequence of the fires being slackened between Saturday and Monday, which increases considerably the size of the crystals.

I am indebted to Dr. Thomson of Edinburgh, (who gave me his assistance with great zeal and alacrity) for an opportunity of examining upwards of twenty specimens of Scotch salt, prepared by different manutazturers. That distinguished chemist, it appears from a letter which he addressed to me on the subjer l, was some time ago engaged in experiments on Cheshire salt. The particulars he has lost ; and he retains only a general recollection of the facts, which confirms, I am bappy to state, the accuracy of the results obtained by my own experiments.

At Lymington in Hampshire, advantage is taken of the greater heat of the climate, to concentrate the sea water by opontaneous evaporation to about one-sixth its bulk, before admitting it into the boilers. One kind of salt is chiefly prepared there, which most nearly resembles in grain the stoved salt of Cheshire. The process varies littie, in some respects, from that which has been already described. The salt is not fished (as it is termed) out of the boiler, and drained in baskets; but the water is entirely evaporated, and the whole mass of salt taken out at once, every eight hours, and removed into troughs with holes in the bottom.

* Che hire Reports, p. 5s, \&c.

Through 
Through these it drains into pits made under ground, which receive the liquor called littern or litter liquor. Under the troughs, and in a line with the holes, are fixed upright stakes, on which a portion of salt that would otiserwise have escaped, crystallizes and forms, in the course of ten or twelve days, on each stake, a mass of sixty or eighty pounds. These lumps are called salt cats. They bear the proportion to the common salt, made from the same brine, of one ton to 100 .

From the mother brine or bitter liquor, which has drained into the pits, the sulphate of magnesia is made during the winter seasnn, when the manufacture of salt is suspended, in consequence of the want of the temperature required for the spontaneous evaporation of the sea water. The process is a very simple one *. The bitter liquor from the pits is boiled for some hours in the pans, which are used in sum. mer to prepare common salt; and the impurities, which rise to the surface, are removed by skimming. During the evaporation, a portion of common salt separates; and this, as it is too impure for use, is reserved for the purpose of concentrating the brine in summer. The evaporated bitter liquor is then removed into wooden coolers eight feet long, five feet wide, and one foot deep. In these it remains twenty-four hours, during which time, if the weather prove clear and cold, the sulphate of magnesia; or Epsom salt, crystallizes at the bottom of the coolers, in quantity equal to about one-eighth of the boiled liquor. The uncrystallizable fluid is then let off through plug-holes at the bottom of the coolers; and the Epsom salt, after heing drained in baskets, is deposited in the store-house. This is termed single Epsom salts, and after solution and a stcond crystallization, it acquires the name of double Epsom salts. Four or five tons of sulphate of magnesia are proauced from a quantity of brine, which has yielded 100 tons of common, and one ton of cat salt.

On the banks of the Mersey, near its junction with the

* I an indebted for an account of this process, as well as of the method of making common salt at Lymington, to the liberal communication of Charles St. Barbe, esq. of that place. 'Though not strictly conuected with the subject, I give his description of the mode of making Epsom salt, because no correct statement of the process has, I believe, been hitherto published. The analysis of sea water, indeed, by a justly distinguished chemist (Bergman), excludes, erroneously, the sulphate of magnesia from its composition, and his results have led to the opinion, that to manufacture this salt on the large scale, requires the addition either of sulphuric acid, or of some sulphate to the lilter liquor. (See Aikin's Chemical Dictionary, ij. \$88.) 
Irish Channel, the water of that river before evaporation is brought to the state of a saturated brine, by the addition of rock salt. The advantage of this method of proceeding will be obvious when it is stated, that 100 tons of this brine yield at least 23 tons of common salt, whereas from the same quantity of sea water, with an equal expenditure of fuel, only two tons $17 \mathrm{cwt}$. of salt can be produced *

Within the few past years, an altempt has been made to apply rock salt itself to the packing of provisions. For this purpese it is crushed to the proper size between iron rollers. The trials which have been made, I am informed, are but few, and the results hitherto are not perfectlyknown.

The bay salt imported from foreign countries is well known to be prepared by the spontaneous evaporation of sea water, which, for this purpose, is confined in shallow pits, and exposed to the full influence of the sun and air. I have no addition to make to the accounts of its manufacture, which have already been given by various writerst.

As the results of the investigation, which forms the subject of this memoir, may be acceptable to many persons who can scarcely be expected to take an interest in a long detail of analytical processes, I shall present, in the following section, a general view of the experiments, and of the conclusions that may be deduced from them. In the last place, in order that other chemists may be enabled to repeat the analyses under similar circumstances, 1 shall describe minutely the methods that were adopted, some of which are new, and others reduced to greater precision. If, however, in the future progress of science, it should appear that any of these processes are imperfect, it may still be admitted that, for all useful purposes, they afford a fair comparison of the composition of the several varieties of culinary salt; since the sources of fallacy, that may hereafter be discovered, must have been the same in every case, and have produced in each an error of nearly the same amount.

\section{SEcr. II. General Statement of the Results of the Experi- ments, and Conclusions thut may be deduced from them.}

A comparison of the component parts of British and

* See the Earl of DundonaId's "Thoughts on the Manufacture and Trade of Salt." I, ondon, 3785.

$t$ Encyclup. Method. art. Salins. (Des Marais Salans) Aikin's Dictionary of Chemistry, ii. 224. Watson's Chemistry, vol. ii. p. 52. It is necessary to remark, that a great proportion of what is sold in Louden as bay-salt is Cheshire laigc-grained fiahcry salt. foresgn 
foreign salts, and of different varieties of British salt with each other, will best be made by an examination of the following table, which comprehends the results of the analysis of equal weights of each variety.

1000 parts by weight consist of

\begin{tabular}{|c|c|c|c|c|c|c|c|c|c|c|}
\hline & Kind of Salt. & 它趝 & 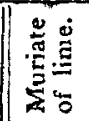 & 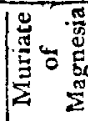 & 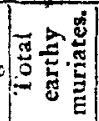 & $\|$ & 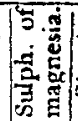 & 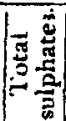 & 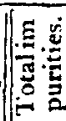 & $\begin{array}{l}\text { Pure } \\
\text { muri- } \\
\text { ate of } \\
\text { soda. }\end{array}$ \\
\hline 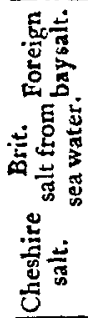 & 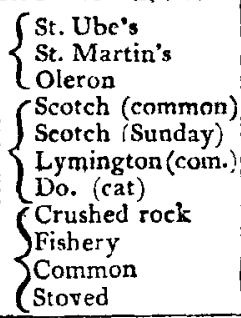 & $\begin{array}{r}9 \\
12 \\
10 \\
4 \\
1 \\
2 \\
1 \\
10 \\
1 \\
1 \\
1 \\
\end{array}$ & $\begin{array}{l}\text { a trace } \\
\text { do. } \\
\text { do. } \\
= \\
= \\
= \\
0 \cdot \frac{1}{16} \\
0 . \frac{1}{4} \\
0 \cdot \frac{1}{4} \\
0 \cdot \frac{5}{4}\end{array}$ & \begin{tabular}{|c}
8 \\
$3 \frac{5}{2}$ \\
2 \\
28 or \\
$11 \frac{1}{2}$ \\
11 \\
5 \\
$0 \cdot \frac{3}{16}$ \\
0.3 \\
$0 \cdot \frac{3}{4}$ \\
0.3 \\
\end{tabular} & $\left|\begin{array}{c}* 3 \\
* 3 \\
32 \\
28 \\
28 \text { or } \\
11 \frac{1}{2} \\
11 \text { or } \\
5 \\
0 * \\
1 \\
1 \\
1\end{array}\right|$ & $\begin{array}{l}23 \frac{1}{2} \\
19 \\
19 \frac{1}{2} \\
15 \\
12 \\
15 \\
1 \\
6 \frac{\pi}{2} \\
11 \\
14 \\
15 \frac{1}{2} \\
\end{array}$ & $\mid \begin{array}{c}4 \frac{1}{2} \\
6 \\
4 \frac{1}{2} \\
17 \frac{1}{2} \\
4 \\
85 \\
5 \\
- \\
- \\
- \\
-\end{array}$ & $\begin{array}{c}28 \\
25 \\
23 \\
32 \frac{1}{2} \\
16 \\
50 \\
6 \\
6 \\
6 \frac{1}{2} \\
11 \frac{1}{14} \\
15 \frac{1}{2}\end{array}$ & \begin{tabular}{|l}
40 \\
$40 \frac{3}{2}$ \\
$35 \frac{3}{2}$ \\
$64 \frac{1}{2}$ \\
29 \\
63 \\
12 \\
$16 \frac{3}{13}$ \\
16 \\
$16 \frac{1}{17}$ \\
$17 \frac{1}{2}$
\end{tabular} & 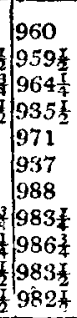 \\
\hline
\end{tabular}

I. The tolal amount of impurities, and the quantity of real muriate of soda, contained in each variety of common salt, may be learned by inspecting the two last columns of the table. From these it appears, that the foreign bay salt is purer, generally speaking, than salt which is prepared by the rapid evaporation of sea water; but that it is contaminated with about three times the amount of impurities discoverable in an equal weight of the Cheshire largegrained salt, and with more than twice that of those that are found in the stoved and common salt of the same district.

II. The insolulle matter in the foreign salt, after the action of boiling water, appears to he chiefly argillaceous earth coloured by oxide of iron, and is probably derived in part from the pits in which the sea water is submitted to exaporation. We may, perhaps, assign the same origin to the very minute portion of muriate of lime, which is not found in the salt prepared by evaporating sea water in metallic vesscls, nor even in the mother liquor, or uncrystallizable residue. In sea salt prepared by rapid evaporation, the insoluble portion is a mixture of carbonate of lime with carbonate of magnesia, and a fine siliceous sand; and in the salt prepared from Cheshire brine, it is almost entirely carbonate of lime. The insoluble part of the less pure pieces of rock salt is chiefly a marly earth, with some sulphate of lime. The quantity of this impurity, as it is staled in the table, is considerably below the average, which in my experiments has varied from 10 to 45 parts in 1000 . 
Some estimate of its general proportion, when ascertained on a larger scale, may the formed from the fact that Government, in levying the duties, allows 65lb. to the bushel of rock salt, instead of $56 \mathrm{lb}$., the usual weight of a bushel of salt.

III. The earthy muriates, and espccially that with base of magnesia, abound most in salt which is prepared by the rapid evaporation of sea water. Now since common salt, in all its forms, contains, as will afterwards appear, very little water of crystallization, it is probable that the muriate of magnesia, discovered by the analysis of sea salt, is derived entirely from that portion of the mother liquor which adheres to the salt after being drained, and which amounts to about one-seventh of its weight. The larger the size of the grain, the less is the quantity of this solution which the sa't holds suspended; and honce the salt prepared at a lower degree of heal, being in larger crystals, is less debased by the magnesiai muriate, lhan the salt formed at a boiling temperature. It is probable, also, that when the salt is dran u at inturvals from the boiler, the proportion of the earthy muriate will vary with the period of the evaporation at which it is remover. For it may readily be conceived, that as the proportion of the cartly muriates in any brine is increased by the separation of muriate of soda, the greater will be the quantity of the nuriates which the crystals of common salt, formed in the midst of the brine, will retain; thence it follows, that, so far as the earthy muriates only are concerned, salt must diminish in purity as the process of evaporation advances.

lis the several varicties of Chcshire salt, the eartby muriates do not exceed one thousandth part of this weight, and they are precisely (or so nearly so that the difference is not ascertainable) the same in all. This $u i l l$ cease to be matter of surprise, when it is considered that the salt obtainer by evaporating to dryness the whole of a portion of Chestire brine, does not give more than five parts of earthy murates in 1000 . In the entire salt of sca water, accord. ing to Bergman, the earihy muriates form no less than 213 parts in the same quantity.

According to the proportion in which the earthy muriates are present in any kind of salt, with be its power of deliquescence, or of attracting moisture from the atmosphere. It is not entirely, however, from the salts with earthy base that common salt derives this quality; for the most transparent specimens of rock salt, which I find to Vol. 36. No. 148. August 1810 . II consist 
consist of absolutely pure muriate of soda, attract much moisture from a humid atmosphere.

IV. The sulphate of magnesia and the sulphate of lime both enter into the composition of all the varieties of salt prepared from sea water; but the sulphate of lime alone is found in Cheshire salt. The proportion of sulphate of magnesia is greatest in that vartety of tea sal: which has been formed by rapid evaporation. In foreign bay salt its quantity is very insignificant.

From the table it may ke seen, that the proportion of sulphate of lime is greater in foreign bay salt than in any variety of British salt, even than in those which are prepared from sea water with a boiling heat. The only explanation of this fact, that occurs to me, is, that during the rapid evaporation of sea water a cousiderable part of. the calcareous sulphate is precipitated at an earty slagre of the process, and is partly removed in clearing the boiler, a process which can scarcely be performed during the formation of bay salt, in pits whose sides are composed of moist clay. The remainder of the sclenite, thus precipitated by the rapid evaporation of sea water, enters into the composition of the pan-scale.

In the course of this inquiry I was induced to repeat the same experiments several times, on various specimens of salt bearing the same designation; and was surprised to find that the restits by no meaus corresponded. In one instance, for example, fishery salt was found in 1000 parts to contain no less then 16 parts of sulphate of lime; while another spccimen, nominally the same, contained only $11 \frac{1}{4}$ parts of selenite in the same quantity; and a third only $5 \frac{3}{4}$. At length it occurred to me that these differences were probably owing to the circumstance of the salt having been taken from the boiler at different periods of the evaporation. I requested, therefore, to be furnished with specimens of salt, drawn at difierent stages of the process from a miven portion of brine, evaporated in the same boiler. These were submitied to analysis; and the results are shown in the following table.

Common salt drawn from the boiler two Sulphate hours after the first application of heat .. Salt drawn four hours after do. ......... Salt drawn six hours after do..........

Hence it appears that there was a gradually increasing purity in the salt from sulphate of lime, as the process of craporation 
evaporation advanced, the greatest part of this earthy compound being depusited at an early stage of the process. Different specimens of the same kind of salt may, therefore, differ in chemical purity as much from each other as from other varicties. But when the impurities contained in a sulution of muriate of soda are of a difierent species from those of Chenive brine, and consist chiefly of the earthy muriates, the order will be reversed, and the purest salt, as I have already suggested, will be that which is first deposited. the contamination with the muriate of lime or of magnesia continuing to increase as the process advances to a cunclusion $*$.

At an early period of the inquiry, it appeared to ine probable that the differences between the sever.l varieties of culinary salt might depend, in some degree, on their containing variable proportions of water of cristallization. It was found, however, by experiment, that the proportion of water in any variety of conmon salt, after being dried at 21 $2^{2}$ Fahrenheit, is not much greater or less than that which is contained in any other varuty. Pure transparent rocksalt, calcined for half an hour in a low red heat, $\left(=4^{\circ}\right.$ or $5^{\circ}$ of Wedgwood's pyrometer,) list absolutely wothing of its weight. It is remarkable, also, that the pure matre salt, if free from adventitious moisure, may be suddenly and stronsly heatcd, with scarcely any of that sound called decripitationt, which is produced by the similar treament of all the varicties of artificial salt. Even these varietics, bowever, exposed during equal times to a low red heat, do not lose more than from halt a grain to three grains in one hundred. This comparison camnot be extended to the salt prepared at a boilmg temperature from sea water; becanse the murriate of magnesia which these varieties contain, is decomposed at a red hoat, and deprived of its acid.

* I cannot on any other mi ciple explain the ronciderable diferences, as to the propo:tion of muriate of mapnesia, that werz discove: $d$ in the se-

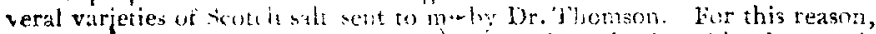

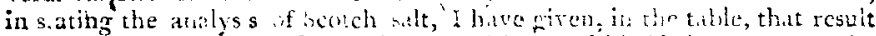
which was most trenuendy olutai col; and bave withined the names of the

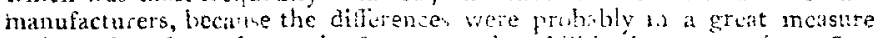
accidental, and not he res!lt of trenter or less shill in the preparation. One specimen of Lymingun silt which $i$ eamined, contained fully as nuth

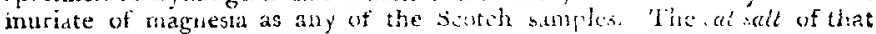
place, however, contrary to my ex" cest ion, proved to posses: a very ex-

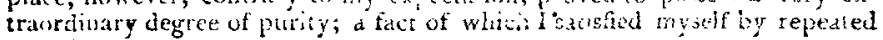
experiments.

+ Decrepitation is occasioned by the sudder conversion into vaponr of the water contained in salts, wher its quautity is insufficient to effect the watery fusim. It is a property pecultire to sults which hoild only a vesy small proportion of vater in combinarion; as muriate of sodd, nitrat of lead, and sulphate of potash.

H 2

Th: 
The following table shows the quantity of water contained in several kinds of salt, inferred from the loss which they sustain by ignition during equal times, after being first dried at $212^{\circ}$.

100 parts of large-grained fishery salt contain of water ........................ 3

$100 \ldots . . \ldots$ foreign bay salt (St. Martin's) .... 3

$100 \ldots \ldots \ldots$ ditto ........... (Oleron) ....... $2 \frac{1}{2}$

$100 \ldots \ldots \ldots$ ditto, Cheshire common salt ....... $1 \frac{1}{2}$

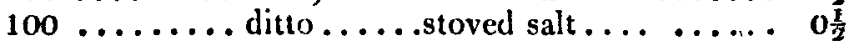

The loudness and violence of the decrepitation was, as ncarly as could be judged, in the same order, and was most remarkabje in the large-grained varieties.

To deterunine the proportions of real muriate of soda in those varieties of artificial salt which are nearly free from earthy muriates, I employed also the process of decomposition by nitrate of silver. The following are the quantities of fused luna cornea obtained from 100 grains of each of three varieties dried, previously to solution, at the temperature of $212^{\circ}$ Fahrenheit.

$100 \mathrm{gr}$. pure transparent rock salt gave of luna cornea ........................242

$100 \ldots$... stoved salt, remarkably pure ......... 239

100 ... fishery salt. do..............237*

The proportion of ingredients in the several kinds of muriate of soda (setting apart the impurities) appears, therefore, to be nearly the same in all. And as the very minute quantity of water discovered by analysis is not constant in the several varieties, it may be inferred to be rather an accidental than a necessary ingredicnt; for in the latter case an invariable proportion might be expected, conformably to the important law, establishing an uniformity in the proportions of chemical compounds. which has been explained by Mr. Dalton, and confirmed by Drs. Thomson and Wollaston.

What then, it may be inquired, is the cause of those

* From 100 grains of pure artificial muriate of soda, previously heated to redness, Dr. Marcet has since informed me that he obtained 24.16 grains of fused luna cornea. The weights of the precipitates thrown down in $m y$ experiments by nitrate of silver are not, I am awate, exactly those which might have been expected from the table of the comparative proporions of water given in the text. Each experiment, however, was twice repeated with every precaution $l$ could adopt, and with the same results. That different kinds of salt give different proportions of luna cornea, is proved also by comparing the experiment of Dr. Marcet with the results of Dr. Black and Klaproth, both of whom found the fused mutiate of silver from 100 parts of common salt to weigh 235 graíns.

differences 
differences which are acknowledged, on all hands, to exist among the several species of muriate of soda, so far as respects their fitness for oconomical purposes? If I were to hazard an opinion, on a subject about which there must still be some uncertainty, it would be that the differences of chemical composition, discovered by the preceding train of experiments, in the several varieties of culinary salt, are scarcely sufficient to account for those properties which are imputed to them on the ground of experience. The stoved and fishery salt, for example, though differing in a very trivid degrce as to the kind or proportion of their ingredients, are adapted to widely different uses. Thus the large-grained salt is peculiarly fitted for the packing of fish and other provisions, a purpose to which the smallgrained salts s re much less suitable. Their different powers, then, of preserving food must depend on some mechanical property; and the only obvious one is the magnitude of the crystals, and their degree of compactness and hardness. Quickness of solution, it is. well known, is pretty nearly proportional, all other circumstances being equal to the quantity of surface exposed. And since the surfaces of cubes are as the squares of their sides, it shou'd follow that a salt whose crystals are of a given magnitude will dissolve four times nore slowly than one whose cubes have only half the size.

That kind of salt, then, which possesses most eminently the combined properties of hardness, compactness, and perfection of crystals, will be best adapted to the purpose of packing fish and other provisions. because it will remain permanenily between the different layers, or will be very gradually dissolved by the fluids that exude from the provisions; thus fumishing a slow but constant supply of saturated brine. On the other hand, for the purpose of preparing the pickle, or of striking the meat, which is done by immersion in a saturated solution of salt, the smallergrained varieties answer equally well; or, on account of their gieater solubility, even better.

With the hardness or strong aggregation of the several varieties of salt, it scemed to ine not improbable that their specific gravity might in some degree be connected. The exact determination of this property in saline substances is, however, a problem of considerable difficulty, as will sufficiently appear from the various results which have been given, with respect to the same salts, by different experimentalists. Thus Muschembroek makes the specific gravity of artificial muriate of soda to vary frum 1918 to 2148 , $\mathrm{H} 3$ 
the mean of which is 2033. Sir Isaac Newton states it at 214.3, and Hassenfrat $z$ at $2200^{*}$. All that was necessary for my purpose was an approximation to the truth; and the introduction of a small error could be of no importance, provided it were the same in every case, since the comparison would still hold good.

The specific gravity of rock salt, there can be little diff. culty in determining with precision. A piece of this salt $t$, of such perfect transparency that I had rescrved it as a cabinet specimen, weighed in the air 513 grains, and lost, when weighed in alcohol, $19+$ grains. The alcobol, at the temperature of $56^{\circ}$ Fahrenheit, had the specific gravity of 820, and hence that of the salt may be estimated at 2170 , Another specimen considerably less pure, and more approaching to a fibrous fracture, had the specific gravity of 2.125 only.

For ascertaining the specific weights of artificial varieties of salıs, I used a very simple contrivance. It consisted of a glass globe about $3 \frac{1}{3}$ diameter, having a stem or neck 10 inches long. Sixteen cubic inches of water (each $252 \frac{1}{4}$ grains at $60^{\circ}$ Fahrenheit,) filled the whole of the globe, and about half an inch of the lower part of the neck; and from the line wbere the water stood in the instrument, it was accurately graduated upwards into hundredth parts of a cubical inch. Into this vessel I poured exactly sixteen cubic inches of a perfectly saturated solution of common salt; and then added 400 grains of the salt under examination, washing down the particles that adhered to the neck by a portion of the liquid, which had been previously taken out of the glabe for the purpose. As much as possible of the air which adhered to the salt was dislodged by agitation, and the increase of bulk was then observed.

Care was taken that the salts were all of equal temperature and dryness, and that no change of temperature happened during the experiment.

\begin{tabular}{|c|c|c|}
\hline \multirow{2}{*}{$\begin{array}{c}400 \text { grains of the less pure kind of rock } \\
\text { salt, broken down into small frag- } \\
\text { ments, filled the space of ........ }\end{array}$} & \multicolumn{2}{|c|}{$\begin{array}{l}\text { Hundred hs Hence its } \\
\text { of a cub. in. specific } \\
\text { grav.wist }\end{array}$} \\
\hline & 75 & $2112^{\circ}$ \\
\hline $4 \mathrm{CO}$ grains of stoved salt. & 7.5 & 2112 \\
\hline $100 \mathrm{~d} o . \quad$ (an & 70 & 2084 \\
\hline$(400 \mathrm{do} . \quad \mathrm{con}$ & 76 & 2084 \\
\hline rge gra & 83 & 1909 \\
\hline (at & 83 & 1909 \\
\hline D & 82 & 1932 \\
\hline
\end{tabular}

* Autales de Chimie, vol. xxviii. p. 13.

+ Foldated rock salt of Jameson. See his Mineralogy, vol. ii. p. 10. $\ddagger$ Distlied water at 1000 being taken as the standard. 
If the above mode of determination at all approach to correctness, it would appear that the specific gravity of rock salt is diminished, by being broken into small fragments, from 212.5 to 2112 , probably in consequence of the quantity of air which the fragments envelop, and which cannot be entirely separated by agitation. From the numbars given in the last column, it is evident that the smallergrained salts are specifically heavicr than those which are composed of larger and more perfect crystals. A difference of only one or two hundredth parts of a cubic inch is perhaps entitled, in a process of this kind, to little rcliance; and I do not therefore regard it as indicating any material difference in the specific gravity of the first four or last three salts submitted to cxperiment. But when the difference anounts to eight hundredths, as between the smalland large-grained sall, it may safely be imputed to an inferior specific gravity in that species, which occupies so much greater a proporional bulk *.

The last series of experiments proves decisively, that in an important quality, (viz. that of specific gravity, ) which is probably connectid with the mechanical property of hardness and coimpactness of crystals, little or no difference is discoverable betwcen the large-grained salt of British, and that of foreign manufacture. If no superiority, then, be claimed for British salt as applicable to oconomical purposes, on account of the greater degree of chemical purity which unquestionably belongs to it, it may safely, I believe, be asserted that the larger-grained rarieties are, as (1) their mechanical properties, fully equal to the foreign bay salt. And the period, it may be hoped, is not far distant, when a prejudice (for such, from the result of this investigation, it appears to be,) will be done away, which has long proved injurions to the interests and prosperity of an important branch of British manufacture.

[To be continued.]

XIX. Description of a Vetallic Thermometer for indicating the higher Degrees of Temperature.

$$
\text { To Mr. Tilloch. }
$$

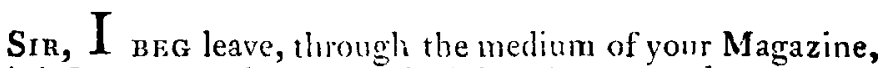
briefly to mention the principle of a new thermometer,

* M Hassenfratz spens to have suspectel that a difference in the specific gravity of the same salt may le secasiuned by a variation in its state of

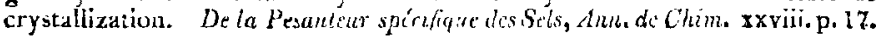

